необходимо как можно большее внимание обращуать на развитие коммуникативных навыков путем как монологического, так и диалогического вещуания. Наиболее эффективным методом формирования иноязычной коммуникативной компетенции студентов является именно диалогическая речь.

Статья посвящуена освещуению и обобщуению научно-методических средств развития диалогической речи, которые используются в прочессе практических занятий вузов. Выделены дидактические аспекты диалогической речи в контексте коммуникативного подхода к изучению языка, приведены методические стратегии, направленные на развитие диалогической речи, как одного из ключевых методов формирования иноязычной коммуникативной компетенции (напр., “Тематическая дискуссия”, “Групповое исследования”, “Телефонный разговор” и др.). Акцентируется внимание на преимуществах использования диалогической речи со студентами, изучающими английский язык, как иностранный, в русле приобретения навыков коммуникативной компетенции.

Ключевые слова: диалогчческая речь, английский язык, коммуникативные компетенции, студентьл, практика, навыки.

KHYZHUN Y. V., DYSHLEVA S. M. Development of dialogue speech of university students: aspects and perspectives of use.

Current realities indicate a steady growth in the need for communication and cooperation between people of different nationalities and cultures, and the changed system of education and the state educational standard of a foreign language induce significant changes in the approach to the teaching process, to the revision and updating of didactic methods of teaching foreign languages in institutions of higher education.

The article is dedicated to the coverage and generalization of scientific and methodological means of the dialogue speech development, which are used in the process of practical training of universities. The didactic aspects of dialogical speech in the context of the communicative approach to language learning are highlighted, some methodological strategies aimed at developing dialogue speech as one of the key methods of forming a foreign language communication competence (for example, "Thematic discussion", "Group research", "Telephone conversation" etc.). The emphasis is on the benefits of using dialogic speech with students who study English as a foreign language in the context of acquiring skills in communicative competence.

Keywords: dialogic speech, English, communicative competenses, students, practice, skills.

DOI: https://doi.org/10.31392/NZ-npu-143.2019.25

УДК 378. 147

Черняк В. О.

\title{
ВИКОРИСТАННЯ НАОЧНОСТІ У ПРОЦЕСІ ВИВЧЕННЯ АНГЛІЙСЬКОї МОВИ У МОЛОДШІЙ ШКОЛІ ЗА ПІДРУЧНИКОМ "FLY HІGH"
}

Одним з резервів інтенсифікащії процесу навчання іноземної мови є використання засобів наочності. Наочні засоби при навчанні іноземної мови використовуються для ілюстрації матеріалу, для створення наочної опори при презентації будь-якої ситуаиї̈, стимулюючої спілкування. Особливу важливість представляє ефективність наочності, використовуваної у 
підручниках-компонентах навчально-методичного комплекту з іноземної мови як основного засобу роботи на уроиі. Сьогодні з'явилося досить багато вітчизняних $i$ зарубіжних підручників з іноземної мови. Однак зарубіжні навчально-методичні комплекти використовуються нечасто. Саме тому в статті проводиться аналіз навчально-методичного комплекту "FLY HIGH”, а також розглядаються приклади використання наочності у процесі викладання англійської мови в молодшій школі, яка передбачає активну розумову діяльність учнів, в основі якої лежить єдність аналітичної і синтетичної форм мислення.

Загальновідомо, що ефективність навчання залежить від ступеня залучення до сприйняття всіх органів почуття людини. Чим різноманітніші чуттеві сприйняття навчального матеріалу, тим міцніше він засвоюється. Ця закономірність знайшла своє вираження у дидактичному приниипі наочності. Наочні засоби навчання - ие частина навчальної техніки, що представляє собою екранно-звукові засоби, друковані посібники, натурні об'єкти, моделі, муляжі, що передають зміст через зображення, звук, анімацію та кінетику.

Наочність посилює інтерес школярів до навчання $і$ значно полегшує цей прочес. Як правило, заняття, на яких використовуються ілюстраиії, фотографії, слайди, проходять із підвищеним інтересом та увагою всіх учнів. Інший позитивний ефект застосування наочності - більш міцне засвоєння інформачії. Приклади і образи запам'ятовуються легше $i$ надовго зберігаються в пам'яті.

Ключові слова: англійська мова, вправи, засіб навчання, навчальний матеріал, наочність, навчально-методичний комплект, підручник, система освіти.

Проблема наочності в навчанні іноземних мов була актуальною в усі часи. Останніми роками у зв'язку з прагненням людства до “суспільства без кордонів", прилучення до культурної спадщини і духовних цінностей народів світу знання іноземної мови як інструменту міжкультурної комунікації стало престижним і затребуваним. Тому помітно розширилася сфера наочності і ускладнився їі інвентар: від предметів і картинок, жестів і рухів до відеофільмів і комп'ютерних програм, за допомогою яких викладач моделює фррагменти об'єктивної дійсності. Загальновідомо, що ефективність навчання залежить від ступеня залучення до сприйняття всіх органів почуття людини. Чим різноманітніші чуттєві сприйняття навчального матеріалу, тим міцніше він засвоюється. Ця закономірність знайшла своє вираження у дидактичному принципі наочності.

Автор "Великої дидактики" Я. А. Коменський вважав наочність "золотим правилом навчання". На його думку, "нічого не може бути у свідомості, що заздалегідь не було дано у відчутті” [1, с. 123].

П. І. Підласий розуміє під принципами наочного навчання такі, при яких засвоєння знань значною мірою залежить від наочного посібника і технічних засобів, використовуваних у процесі навчання [2, с. 26].

Проаналізувавши різні визначення наочності, згадані в роботах педагогів i методистів, ми можемо зробити висновок, що наочність - це застосування в практиці викладання спеціальних засобів навчання, заснованих на принципі наочності, згідно з яким навчання базується на безпосередньо сприйнятих образах.

Наочність посилює інтерес школярів до навчання і значно полегшує цей процес. Як правило, заняття, на яких використовуються ілюстрації, фротографії, слайди, проходять із підвищеним інтересом та увагою всіх учнів .

Інший позитивний ефект застосування наочності - більш міцне засвоєння інформації. Приклади і образи запам'ятовуються легше і надовго зберігаються в 
пам'яті.

Педагоги і методисти виділяють основні фрункції наочності на уроках англійської мови:

1) підвищення інтересу учнів до уроку;

2) створення умов для природного використання мовного матеріалу і його застосування в мові;

3) полегшення процесу засвоєння англійської мови;

4) допомога в оволодінні необхідними навичками і вміннями;

5) розвиток уваги і пам'яті.

Що стосується видів наочності, для початку розглянемо визначення наочних засобів навчання.

Наочні засоби навчання - це частина навчальної техніки, що представляє собою екранно-звукові засоби, друковані посібники, натурні об'єкти, моделі, муляжі, що передають зміст через зображення, звук, анімацію та кінетику [3, с. 24].

У навчанні англійської мови наочність класифікується за такими ознаками:

1) за характером сприйняття - безпосередньо-перцептивна, зображальноперцептивна, безпосередньо-мнемічна, зображально-мнемічна;

2) за ступенем натуральності (схематичності) - фрото, малюнок, схема (засоби візуальної наочності); звук, синтетичний звук, спектограма звуку (засоби слухової наочності);

3) за участю органів почуттів - зорова, слухова, рухово-моторна, змішана;

4) щодо мовного матеріалу - мовна, немовна.

Особливу роль на заняттях з англійської мови відіграє образотворча наочність (у класифікації за характером сприйняття вона представлена як зображально-перцептивна), до якої відносять фотографії, малюнки, картини тощо. Засоби образотворчої наочності, як спосіб відображення реальності, сприяють фрормуванню уявлень про світ. Ілюстрації сприяють розвитку уваги, спостережливості, естетичного смаку, культури мислення, пам'яті і підвищують інтерес до вивчення іноземної мови. Принцип наочності сприяє набуттю усвідомлених знань, забезпечує їх міцність засвоєння, викликає пізнавальну активність учнів, здійснює позитивний емоційний вплив і сприяє успішному вирішенню розвиваючих, практичних, освітніх і виховних завдань.

Проаналізувавши різні класифікації видів наочності, ми можемо зробити висновок, що наочність має неоднорідний характер. Вибір викладачем певного виду наочності для використання на уроках залежить від навчального завдання, а також від рівня інтелектуальної діяльності школярів.

Наочність збільшує ефективність навчання, допомагає учневі засвоювати мову більш осмислено і з великим інтересом. Значення наочності вбачають зараз у тому, що вона мобілізує психічну активність учнів, викликає інтерес до занять мовою, розширює обсяг засвоюваного матеріалу, знижує стомлення, тренує творчу уяву, мобілізує волю, полегшує весь процес навчання.

Наочні посібники використовуються на всіх етапах процесу навчання, а саме при: поясненні нового матеріалу; закріпленні знань, фрормуванні умінь і навичок; виконанні домашніх завдань; перевірці засвоєння навчального матеріалу. Якість навчання залежить від правильного застосування вчителем наочних посібників. Аналіз методичної літератури з цього питання дав змогу виділити величезний 
комплекс наочних посібників, рекомендованих для використання у процесі навчання англійської мови. Це різні друковані, екранні, звукові (аудитивні), екранно-звукові (аудіовізуальні) засоби та посібники.

Існують різноманітні класифікації засобів навчання. Загалом, методисти поділяють їх на дві великі групи: основні і додаткові (допоміжні). Навчальнометодичний комплекс (НМК) відносять до основних засобів навчання. Сучасний НМК повинен містити інваріантну частину, до якої входять книга для учнів, аудіокасети до книги для учнів і книга для вчителя. НМК також може містити і додаткові компоненти, склад яких може варіюватися залежно від типу НМК.

Різноманіття технологій навчання і виховання обумовлює проблему оцінки якості навчально-методичних комплектів 3 англійської мови, які повинні відповідати єдиним вимогам як до їх розробки, так і до застосування на практиці.

У результаті аналізу змісту підручника-компонента НMK "Fly High 1" [4] можна зробити висновок, що в підручнику здебільшого представлений такий вигляд наочності, як ілюстрації (образотворча наочність). Однак вони вельми різноманітні і використовуються як при введенні нового матеріалу, так і при його закріпленні і відпрацюванні. Більш того, нова інформація засвоюється учнями не тільки 3 допомогою ілюстрацій, але й через завдання намалювати предмети, що належать до теми уроку. У підручнику є велика кількість наочності, яка стає візуальною опорою для учнів при виконанні різного роду завдань і сприяє кращому запам'ятовуванню матеріалу, адже фрормує у свідомості школярів конкретні образи. Крім цього, у цьому НМК представлена слухова наочність у вигляді пісень, що сприяють закріпленню нового мовного матеріалу, а також його більш ефективному засвоєнню.

Розглянемо детально використання наочності під час викладання англійської мови за підручником із НМК "Fly High". Вивчення теми "In the jungle" починається 3 таких завдань: Listen and point. Then say. Учні, маючи перед собою зоровий образ тварин, чують ще й звуки, які вони видають (див. рис. 1):

\section{1) Listen and point. Then say.}

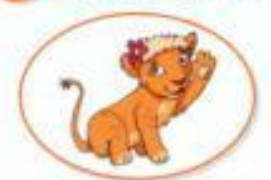

lion

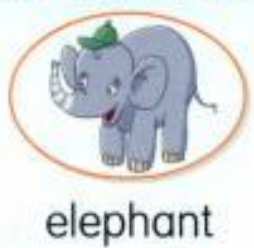

elephant

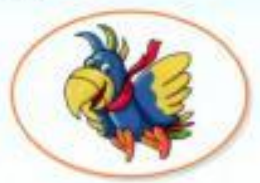

parrot

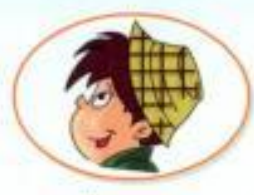

boy

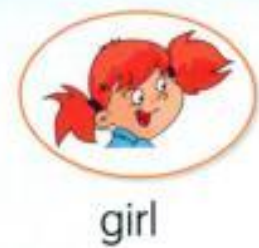

girl

Рис. 1. Приклад вправи на ознайомлення з лексичним матеріалом із використанням наочності

У підручнику аудійний формат постійно об'єднується із візуальним. Це обумовлено тим, що учні краще розуміють, про що йдеться у аудіозапису, якщо він буде супроводжуватися допоміжним візуальним контентом. У цьому випадку це може бути історія про тварин, яка супроводжується номерами для того, щоб учень зрозумів послідовність дій у розповіді та зображеннями тварин (див. рис. 2). 


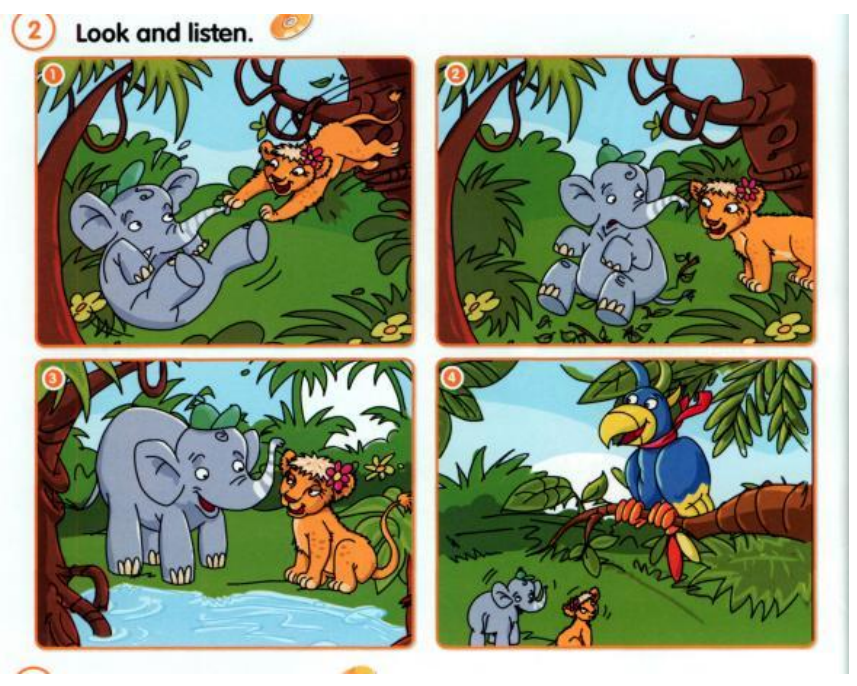

Рис. 2. Приклад вправи з навчання аудіювання із використанням наочності

Навчання кольорам відбувається шляхом використання малюнків, які нагадують розмальовку, а учням можна запропонувати зробити власні малюнки, використовуючи зразок із підручника (див. рис. 3). Таким чином, учні зможуть запам'ятати назви кольорів шляхом розмальовування, тобто безпосередньої роботи з кольорами.

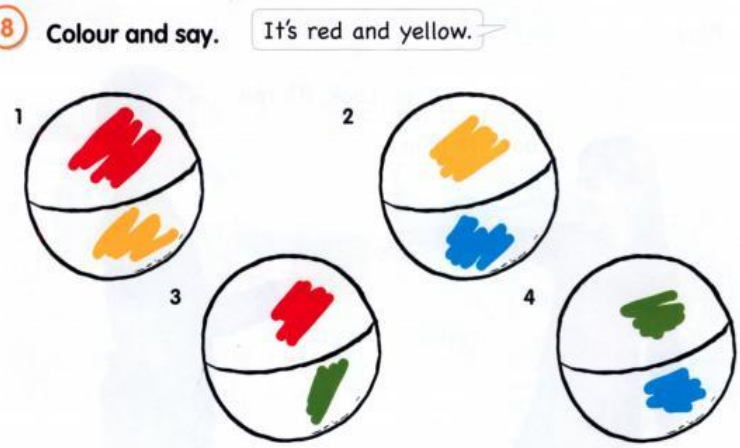

Рис. 3. Приклад вправи на ознайомлення з лексичним матеріалом із використанням наочності

Аудіальні компоненти наочності залучають учнів не тільки до прослуховування і розуміння матеріалу за допомогою малюнків, а ще й до подальшого розвитку мовлення. Такою вправою $є$ наступна, де залучається пісня із подальшою її репродукцією (див. рис. 4). 


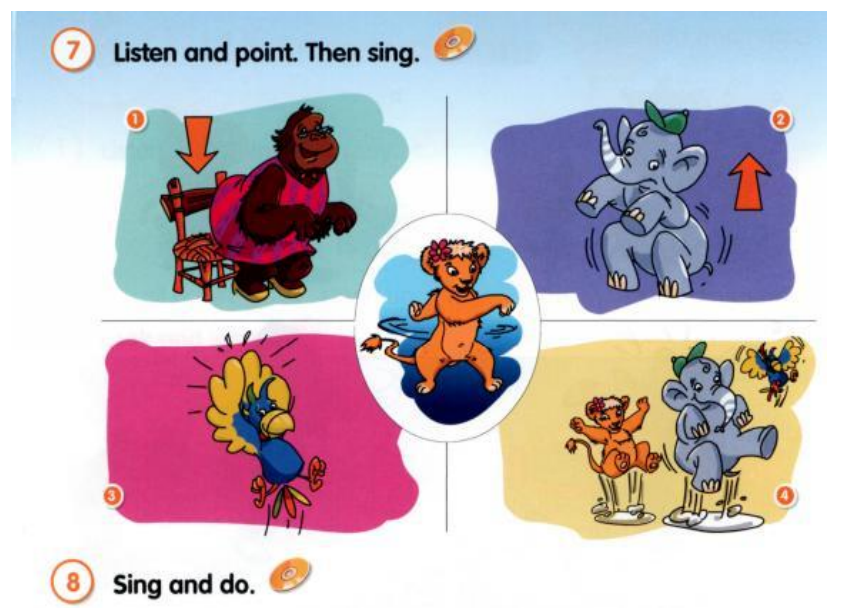

Рис. 4. Приклад вправи на розвиток мовленнєвої навички

У підручнику Fly High пропонуються транскрипційні знаки одночасно 3 літерами, тож наочністю можуть бути транскрипційні знаки. Ознайомивши учнів 3 кількома літерами, звуками та римівками, слід запропонувати їм спершу обрати відповідні літери та звуки до малюнків (скориставшись магнітною дошкою), а тоді продекламувати римівку. Наступним етапом може бути написання букв та звуків. Наприклад: на дошці малюнок з бджілкою на дереві, що п'є чай. 3 вивчених транскрипційних знаків діти вибирають [i: ] та прикріпляють на дошці під малюнком, серед літер алфавіту знаходять Ее та прикріпляють нижче, називають слова з цією літерою з римівки (bee, tree, sea, tea) і декламують римівку:

It's a bee

Sitting in a tree

Drinking tea

By the sea.

Перегляд короткого мультфільму про букви та звуки також буде цікавим та розвиваючим, за допомогою якого учні легко запам'ятають особливості читання букв та буквосполучень (alphablocks, phonicssongs).

Таким чином, наочність у НMK "Fly High" відіграє дуже важливу роль у навчанні іноземної мови. За допомогою картинок вирішуються мовні проблемні завдання при вільному говорінні. Але найголовніше те, що при виконанні вправ із застосуванням наочності із НMK "Fly High", учні говорять і слухають не тому, що зобов'язані це робити, а їм цікаво вирішувати подібні мовні завдання.

Наочність із НMK "Fly High" допомагає учням засвоювати мовний матеріал більш осмислено і з великим інтересом. Крім того, наочність мобілізує психічну активність учнів, викликає інтерес до занять англійською мовою, розширює обсяг засвоюваного матеріалу, знижує стомлення, тренує творчу уяву, мобілізує волю, полегшує весь процес вивчення англійської мови.

Використання наочності в HMK "Fly High" передбачає активну розумову діяльність учнів, в основі якої лежить єдність аналітичної і синтетичної форм мислення. Подібного роду символічні наочності допомагають дитині досить швидко згадати вивчені фрази і невеликі речення, сприяють формуванню всіх видів 
навичок, зокрема і граматичних, і використовувати їх у мовленні, що підтверджує важливість використання наочності в процесі навчання англійської мови.

У результаті проведеного нами аналізу ми дійшли висновку, що в підручниках-компонентах у НMK "FlyHigh" наочність здебільшого представлена у вигляді ілюстрацій, але використовується досить доцільно на всіх етапах уроку, сприяючи формуванню у свідомості школярів конкретних образів.

\section{Використана література:}

1. Коменский Я. А. Избранные педагогические сочинения : в 2-х т. Т. 2. Москва : Педагогика, 1982. $576 \mathrm{c}$.

2. Подласый И. П. Педагогика : учебник. 2-е изд., доп. Москва : Юрайт; Высшееобразование, 2010. $574 \mathrm{c}$.

3. Фридман А. М. Наглядность и моделирование в обучении. Москва : Знание, 2010. 56 с.

4. Fly high Pupils book [Електронний ресурс]. Режим доступу: https://vk.com/doc102945518_ 386038890 ?hash $=9174 \mathrm{c} 2 \mathrm{~b} 43 \mathrm{e} 7 \mathrm{~b} 9 \mathrm{f} 7 \mathrm{~d} 18 \& \mathrm{dl}=0 \mathrm{fcb} 5 \mathrm{cb} 2 \mathrm{e} 0 \mathrm{dd} 7 \mathrm{e} 368 \mathrm{c}$

\section{References:}

[1] Komenskiy Ya. A. (1982). Izbrannyye pedagogicheskiye sochineniya: v 2-kh t. T.2. Moskva : Pedagogika. $576 \mathrm{~s}$.

[2] Podlasyy I. P. (2010). Pedagogika : uchebnik. 2-e izd. dop. Moskva : Yurayt; Vyssheyeobrazovaniye. $574 \mathrm{~s}$.

[3] Fridman A. M. (2010). Naglyadnost i modelirovaniye v obuchenii. Moskva : Znaniye. $56 \mathrm{~s}$.

[4] Fly high Pupils book [Електронний pecypc]. Режим доступу: https://vk.com/doc102945518_ 386038890 ?hash $=9174 \mathrm{c} 2 \mathrm{~b} 43 \mathrm{e} 7 \mathrm{~b} 9 \mathrm{f} 7 \mathrm{~d} 18 \& \mathrm{dl}=0 \mathrm{fcb} 5 \mathrm{cb} 2 \mathrm{e} 0 \mathrm{dd} 7 \mathrm{e} 368 \mathrm{c}$

\section{ЧЕРНЯк В. А. Использование наглядности в процессе изучения английскогоязыка в} младшейшколе по учебнику "fly high".

Одним из резервов интенсификаџии прочесса обучения иностранному языку является использование средств наглядности. Наглядные средства при обучении иностранному языку используются для иллюстрации материала, для создания наглядной опоры при презентации какой-либо ситуации, стимулирующей общение. Особую важность представляет эффективность наглядности, используемой в учебниках-компонентах учебно-методического комплекта по иностранному языку как основного средства работы на уроке. В настоящее время появилось довольно много отечественных и зарубежных учебников по иностранному языку. Однако практика использования зарубежных учебно-методических комплектов распространена не так широко. Именно поэтому в статье проводится анализ учебнометодического комплекта “FLY HIGH", а также рассматриваются примеры использования наглядности в прочессе преподавания английского языка в младшей школе, которая предусматривает активную умственную деятельность учеников, в основе которой лежит единство аналитической и синтетической форм мышления.

Общеизвестно, что эффективность обучения зависит от степени привлечения $\kappa$ восприятию всех органов чувства человека. Чем разнообразнее чувственные восприятия учебного материала, тем прочнее он усваивается. Эта закономерность нашла свое выражение в дидактическом принциие наглядности. Наглядные средства обучения - это часть учебной техники, представляющая собой экранно-звуковые средства, печатные пособия, натурные объекты, модели, муляжи, передающие содержание через изображение, звук, анимаџию и кинетику. Наглядность усиливает интерес школьников к учебе и значительно облегчает этот прочесс. Как правило, занятия, на которых используются иллюстрации, фотографии, слайды, проходят с повышенным интересом и вниманием всех учеников. Другой положительный эффект применения наглядности - более прочное усвоение информации. Примеры и образы запоминаются легче и надолго сохраняются в памяти. 
Одним из резервов интенсификаџии процесса обучения иностранному языку является использование средств наглядности. Наглядные средства при обучении иностранному языку используются для иллюстрачии материала, для создания наглядной опоры при презентации какой-либо ситуации, стимулирующей общение. Особую важность представляет эффективность наглядности, используемой в учебниках-компонентах учебно-методического комплекта по иностранному языку как основного средства работы на уроке. В настоящее время появилось довольно много отечественных и зарубежных учебников по иностранному языку. Однако практика использования зарубежных учебно-методических комплектов распространена не так широко. Именно поэтому в статье проводится анализ учебнометодического комплекта “FLY HIGH”, а также рассматриваются примеры использования наглядности в процессе преподавания английского языка в младшей школе, которая предусматривает активную умственную деятельность учеников, в основе которой лежит единство аналитической и синтетической форм мышления.

Общеизвестно, что эффективность обучения зависит от степени привлечения $\kappa$ восприятию всех органов чувства человека. Чем разнообразнее чувственные восприятия учебного материала, тем прочнее он усваивается. Эта закономерность нашла свое выражение в дидактическом принщипе наглядности. Наглядные средства обучения - это часть учебной техники, представляющая собой экранно-звуковые средства, печатные пособия, натурные объекты, модели, муляжи, передаюшие содержание через изображение, звук, анимаџию и кинетику. Наглядность усиливает интерес школьников к учебе и значительно облегчает этот прочесс. Как правило, занятия, на которых используются иллюстрации, фотографии, слайды, проходят с повышенным интересом и вниманием всех учеников. Другой положсительный эффект применения наглядности - более прочное усвоение информаџии. Примеры и образы запоминаются легче и надолго сохраняются в памяти.

Ключевые слова: английский язык, упражснения, средства обучения, учебный материал, наглядность, учебно-методический комплект, учебник, система образования.

CHERNIAK V.A. The use of visibility in the process of learning english in primary school textbook "fly high".

One of the resources for the intensification of the process of teaching a foreign language is using of means of visualization. Visual AIDS of teaching a foreign language are used to illustrate the material, to create a visual prop for the presentation of a situation, to encourage communication. The effectiveness of visibility used in textbooks-components of epy educational and methodical set in a foreign language as the main means of work in the classroom is of particular importance. Currently, there are quite a lot of domestic and foreign textbooks on foreign language. However, the practice of using foreign educational and methodical set is not so widespread. That is why the article analyses the educational and methodical set "FLY HIGH", as well as examples of the use of visibility in the process of teaching English in primary school, which provides for active mental activity of students, which is based on the unity of analytical and synthetic forms of thinking.

Keywords: English language, exercises, educational material, visibility, educational and methodical set, textbook, education system, teaching AIDS. 